\title{
Teaching Learning Traditional Javanese Song Writing trough Paraphrase Technique Based on Javanese Short Story in Senior High School
}

\author{
N Miftakhuzzilvana ${ }^{1}$, M Rohmadi ${ }^{2}$, Sumarwati $^{3}$ \\ ${ }^{1-3}$ Postgraduate Program, Javanese Language and Letters Education, Universitas Sebelas \\ Maret, Surakarta, Indonesia \\ nurlaili.mifta@gmail.com
}

\begin{abstract}
This research aims to improve: 1) learning process in writing the traditional Javanese song, and 2) the ability of learning process in writing Javanese song lyrics through the application of paraphrase technique based on short story to high school students. This research uses the design of class activity research (CAR). The subjects of this research are the java language teacher and $2^{\text {nd }}$ grade science students of Senior High School 1 Tunjungan, Blora, and Central Java. The data collecting is done using the technique of observation, interview, document investigation, and knowledge test in writing Javanese song lyrics, and the data analysis uses the comparative descriptive. The result of this research showed that the technique could improve the learning process quality and ability of learning in writing Javanese song lyrics using paraphrase technique based on short story prasiklus to the first cycle and from cycle I to cycle II. It can be conclude that: (1) learning by using paraphrase based on Javanese short story can increase the learning process quality that before the action amounted to $46 \%$, the first cycle of $71 \%$ and a second cycle of $92 \%$ (2) learning by using paraphrase based on Javanese short story can enhance students' ability to write a traditional Javanese song lyrics of XI IPA 4 senior high school 1 Tunjungan, Blora. Increased ability seen from the students' work before action by 19\%, 59\% first cycle and the second cycle as much as $85 \%$.
\end{abstract}

Keywords: Javanese Learning; Paraphrase Technique; Traditional Javanese Song.

\section{INTRODUCTION}


Javanese is a subjects which is belong to local subject as the regional regulation number 9, 2012 concerning language, literature and Javanese alphabet. In the rule is explained that Javanese subject is implemented at the level of primary, secondary and high school/equivalent at least two hours lesson every weeks of each class. By the rule is hoped that the student able to implement Javanese as mother tongue so that it isn't lost by globalization, but the reality said another.

Many students feel difficult in learning Javanese language and literature. The Evidence is the result from the last semester of XI IPA 4 SMA N 1 Tunjungan, Blora, Central Java. From 27 students who took the final semester test, only 5 students get score more than standart. After conducting interview with some students it is known that the competencies that are considered difficult are the basic competencies of traditional Javanese song (tembang macapat) and Javanese alphabet.

The kind of traditional Javanese song are maskumambang, mijil, sinom, kinanthi, asmarandana, gambuh, dhandhanggula, durma, pangkur, megatruh, pocung [1]. Every kind had different rule and for the gambuh song had rule four $\mathrm{n}$ each stanza consists of five lines, the first line has seven syllables and the final vowel $\mathrm{u}$, the second row has the ten ten syllables and the final sound $\mathrm{u}$, the third row is twelve syllables the end $\mathrm{i}$, the fourth row has eight syllable syllables the final vowel, the last row is eight final sound syllables o. It can be illustrated by 5 lines, $7 \mathrm{u}, 10 \mathrm{u}, 12 \mathrm{i}, 8 \mathrm{u}, 8 \mathrm{o}[2]$.

The respondent said that when they made traditional Javanese song they felt difficult to find the words ending vocal $\mathrm{O}$ in order to fit by the rule of the song (paugeran tembang), difficulty to match the words which will be made to the song based on the theme and using beautiful words (basa rinengga). The rule (paugeran tembang) and the beautiful word (basa rinengga) must be used when students make this [3], [4].

Beside that the researcher knows the problem is not only the students but also in learning process. In learning of traditional Javanese song the teacher still dominate in learning process. The students are only passive. From the problem researcher tries to find the solution which can be alternative to help learning process of the students. The alternative which is given by researcher as the solution in the learning is by paraphrase technique based on Javanese short story (cerkak).

\section{METHOD}

The method used in this research was Classroom Action Research (CAR) which conducted in SMA N 1 Tunjungan, Blora, Central Java. The data research was obtained by interview, observation, test, and documentation. The technique of analyzing data used in this research was comparative descriptive analysis (comparative descriptive statistic and critically analysis technique). Comparative descriptive statistic used for analyzing quantitative data that is comparing the result of each cycle [5]. The data validation tested by using data source triangulation technique. Data source triangulation directed the researcher in getting and collecting available various data. Besides conducting interview, the researcher did observation by using written documents; those were syllabus, lesson plan and list of students score. The planning of Classroom Action Research was done in two cycles. In each cycle consisted of two meetings and there were 4 steps activity in each cycle, those were: planning, implementing the action, observing, and reflecting [6]. 


\section{RESULTS AND DISCUSSION}

The Javanese learning has four aspects; those are paying attention (nyemak), speaking (micara), reading (maca), and writing (nulis) [7]. Writing is a skill that must be practiced through written because they will be brave to share their idea. Furthermore, though written media can increase their smartness, improve their creativity and grow their braveness. Writing is lowered or symbols depicting a graph illustrating a language that can be understood by a person. Writing is a language skills that is used to communicate indirectly [8].

Based on the difficulty gotten by the students, the researcher presents the new technique, which is paraphrase technique based on short story. Through this technique, the students give the short story test that is suited with traditional Javanese song theme. Through that text, the students can get the diction illustration that is able to improve to traditional Javanese song. That technique is similar with paraphrase technique [9]. The meaning is different that information. Meaning is something that is in the speech itself, and information is something that is outside the speech. The way gives border that paraphrase is a way to understand the meaning of an art work by showing back the idea showed by the author by using the different words or sentences than the words used by the author. Paraphrase is defined as the restatement (or reuse) of text giving the meaning in another form [10].

Paraphrase technique based on short story implementation is not only stopped until that step. In learning, the students are given chance to discuss about diction that will be used in making traditional Javanese song. The teacher is also active in helping when the students don't know the meaning of every word. Moreover, the teacher also prepares the dictionary as the accomplice media when the students find new words that are never found before.

The implementing of teaching learning traditional Javanese song writing was done in three activities in each cycle; those were introduction, core activity, and close activity. Each cycle consisted of two meetings, and in each meeting had allocation time 45 minutes. The implementation of teaching and learning in the cycle II was same with the cycle I, however the time allocation given by the teacher for discussion activity in the cycle II was longer, thus the teacher had more time to accompany the students and the students also could ask about the material they did not understand to the teacher and their friends more freely.

The assessment of teaching learning traditional Javanese song writing was done by assessing some aspects that have determined, those aspects were as follows: 1) content and idea; 2) content organization with the rule; 3 ) diction; 4) beautiful word (basa rinengga) [11]. The improvement of traditional Javanese song writing ability can be seen from the increase of the number of the students whose score were above the minimum completeness criteria (75) which described in this following diagram: 
Picture 1. Improving the students' ability of traditional Javanese Song Writing

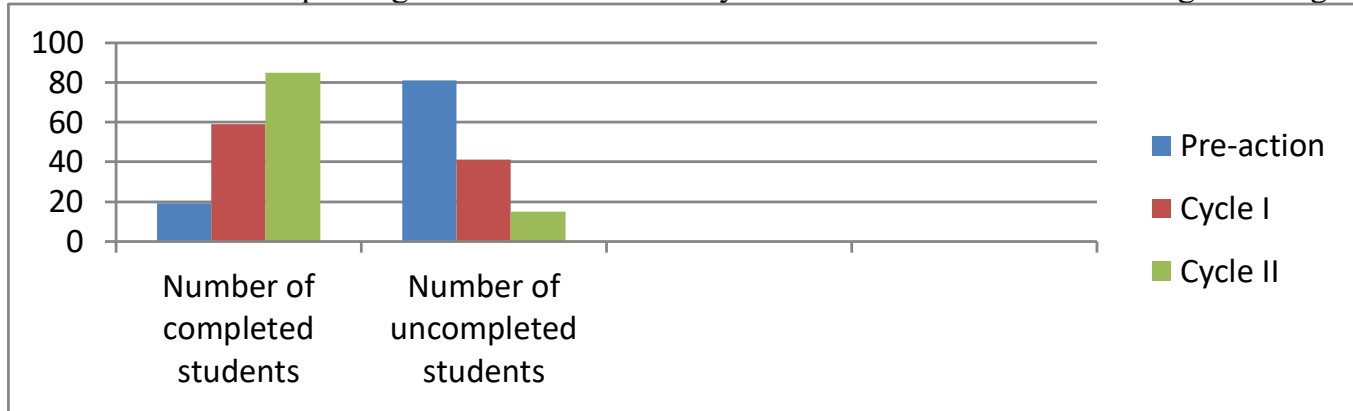

Based on the picture 1 above, it can be seen that the number of completed students whose score could achieve the minimum completeness criteria improved in each cycle. Students whose score could achieve the minimum completeness criteria in pre-action were 5 students or $19 \%$, in the cycle I there were 16 students or $59 \%$ of all students whose score could achieve the minimum completeness criteria, then in the cycle II there were 23 students or $85 \%$ of all students whose score could achieve the minimum completeness criteria.

Furthermore, the improvement was also seen from the average score in each cycle. The improvement can be seen into this following diagram.

Picture 2. The Improvement of Learning Process Traditional Javanese Song Writing

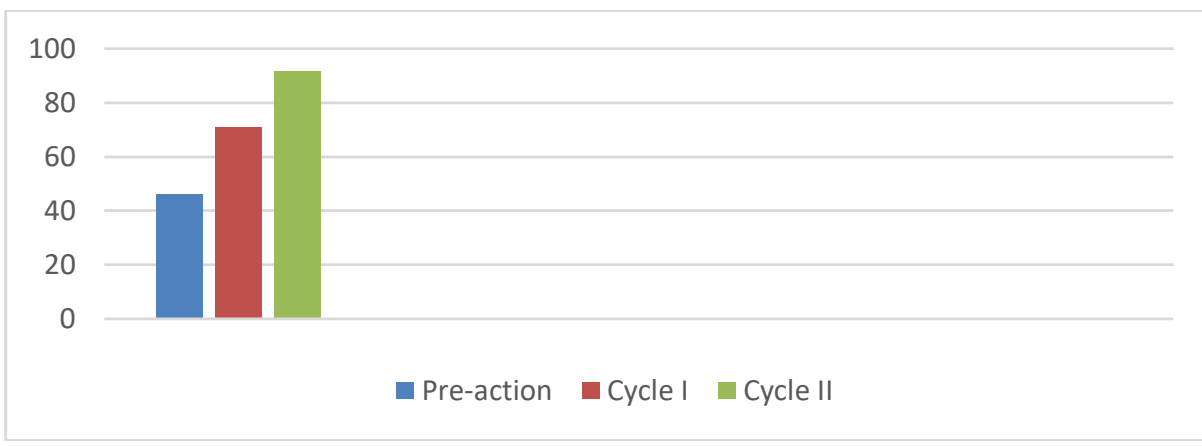

Based on the picture 2, it can be seen that the learning process of Javanese song writing on students class XI IPA 4 SMA Negeri 1 Tunjungan, Blora improved in each cycle. The average score in the pre-action was 46 , and then in cycle I increased to 71, in the cycle II the average score increased to 92 . The improvement can be seen from the quality of traditional Javanese song writing process.

\section{CONCLUSION}

From the discussion above, it can be concluded that paraphrase based on Javanese short story could improve the result of teaching-learning traditional Javanese song writing on students class XI IPA 4 SMA Negeri 1 Tunjungan, Blora. The improvement was also seen from the increasing number of the students who could achieve the minimum completeness criteria in each cycle. In the pre-action there were 5 students or $19 \%$ students who could achieve the minimum completeness criteria. In the cycle I the number of completed students increased to 16 students 
or $59 \%$, then in cycle II the number of completed students improved to 23 students or $85 \%$. Moreover, the average score of quality process in each cycle also improved. In the pre-action, the average score was 46, in cycle I improved to 71, and then in cycle II improved to 92.

\section{REFERENCES}

[1] Santosa and Puji, "Fungsi Sosial Kemasyarakatan Tembang Macapat," Widyaparwa, vol. 44, no. 2, pp. 85-97, 2016.

[2] A. Prihandoko, S. Suwandi, and Sumarlam, "Peningkatan Kemampuan Menemukan Isi dan Pesan Tembang Macapat dengan Pendekatan Quantum Learning pada Siswa Kelas VIIIC Smp Negeri 4 Magetan,” J. Pendidik. Bhs. dan Sastra, vol. 1, no. 1, pp. 1-11, 2013.

[3] D. B. P. Setiyadi, "Asian Journal of Social Sciences \& AMP; Humanities Discourse Analysis of Serat Kalatidha: Javanese Cognition System and Local Wisdom," Asian J. Soc. Sci. Humanit., vol. 2, no. 4, 2013.

[4] A. Efendi, "Mengenal Tembang Macapat," J. Widyatama, vol. 20, no. 2, 2009.

[5] S. Kasinah, "Classroom Action Research," Pionir, vol. 1, no. 1, 2013.

[6] S. Mundziroh, S. Sumarwati, and K. Saddhono, "Peningkatan Kemampuan Menulis Cerita dengan Menggunakan Metode Picture and Picture pada Siswa Sekolah Dasar," BASASTRA J. Penelit. Bahasa, Sastra Indones. dan Pengajarannya, vol. 2, no. 1, pp. 1-10, 2013.

[7] K. Saddhono and M. Rohmadi, "A Sociolinguistics Study on the Use of the Javanese Language in the Learning Process in Primary Schools in Surakarta, Central Java, Indonesia," Int. Educ. Stud., vol. 7, no. 6, May 2014.

[8] K. Saddhono, "The Argumentative Writing Skill with Multicultural Awareness," Int. Sci. Res. J., vol. 72, no. 4, pp. 108-116, 2016.

[9] R. Bhagat and E. Hovy, "What Is a Paraphrase?," Comput. Linguist., vol. 39, no. 3, pp. 463-472, Sep. 2013.

[10] S. Fernando and M. Stevenson, "A Semantic Similarity Approach to Paraphrase Detection," in Proceedings of the 11th Annual Research Colloquium of the UK Special Interest Group for Computational Linguistics (CLUK 2008), 2008.

[11] P. Setiyadi, "Tembang Macapat dan Pemanfaatannya sebagai Media Pendidikan Budi Pekerti Bangsa," Magistra, vol. 24, no. 79, 2012. 